\title{
Growth, Enzyme and Sugar Responses of Immature Sugarcane to Foliar Treatment with 6-Azauracil and Gibberellic Acid
}

\author{
Alex G. Alexander ${ }^{1}$
}

\section{INTRODUCTION}

A reliable means of controlling sugarcane growth has not been found in spite of its potential value to the sugar industry. Effective treatment would require suppression or death of the meristematic areas actively renewing the green-leaf and immature storage tissues. This would enable producers to terminate cane growth and to initiate ripening in accordance with a predetermined production and harvest schedule. In Puerto Rico, where heavy rains cause major sugar losses midway through the grinding season, the treatment might prevent a reversion from the ripened stage back to one of renewed vegetative growth. A more extensive use of growth stimulants and fertilizers might also be possible if growers were certain that they could stop cane growth in time for adequate ripening.

With this question in mind, increasing attention has been given here to certain analogs of purine and pyrimidine which are known to inhibit growth of plant and animal tissues. 8-azaguanine has been shown by several workers to be an effective inhibitor of RNA synthesis $\left(16,{ }^{2} 20,19,18\right)$. In medicine much attention has been given the analogs of purine and pyrimidine during the search for agents helpful in the treatment of human cancer $(25,15)$. Raghavan (24), working with gametophytes of the fern Asplenium nidus, found that induction of 2-dimensional growth can be completely inhibited by antagonists of all the four bases making up RNA. Suppression of perithecia initiation in the ascomycete Sordaria mificola was reportedly accomplished with analogs of three RNA bases (17), but not with those of thymine. Workers in Hawaii have included compounds related to purine and pyrimidine while screening chemicals for cane ripening control (10).

Initial tests in Puerto Rico included foliar treatments with 5-fluorouracil, 5-aminouracil, 6-azauracil, and 8-azaguanine. The pyrimidine analog 6 -azauracil showed definite promise as a growth inhibitor. It caused death of meristematic tissues and terminated the emergence of normal leaves from the spindle while older foliage experienced only slight desiccation.

This paper summarizes recent studies of 6-azauracil as a potential growth. inhibitor and ripening agent. There were four objectives: 1 , To verify

1 Plant Physiologist, Agricultural Experiment Station, Mayagüez Campus, University of Puerto Rico, Rio Piedras, P.R.

2 Italic numbers in parentheses refer to Literature Cited, p. 309. 
growth inhibition and to define more closely the lowest effective level of 6-azauracil; 2, to determine whether the growth effects can be maintained in the presence of a powerful growth stimulant; 3 , to determine the influence of azauracil on sugar and protein constituents of treated plants; and 4 , to ascertain whether inhibitor action can be correlated with activity of essential hydrolytic and oxidative enzymes.

\section{EXPERIMENTAL PROCEDURE}

\section{PREPARATION OF PLANT MATERIALS}

Two experiments were conducted in the greenhouse using a sand-culture technique previously described (1). All plants were of the variety P.R. 980 and treatments were initiated when these were 14 weeks of age. For experiment $I$, the following percentage solutions of 6 -azauracil ${ }^{3}$ were given as foliar sprays: $0.001,0.005,0.01,0.04,0.10$, and 0.40 . These were applied with a hand sprayer until runoff had begun. Tween 20 was used as wetting agent at the rate of 1 milliliter per liter of spray. Control plants received Tween 20 in distilled water. A randomized block design was employed with three replicates for each of the seven treatments.

In experiment II, three levels of 6-azauracil were applied in factorial combination with three levels of gibberellic acid (GA). ${ }^{4}$ Inhibitor concentrations were $0,0.005$ and 0.05 percent, and GA levels were equivalent to 0 , 0.01 and 0.10 percent of the pure acid. Tween 20 was again used as wetting agent. No precipitation occurred when GA and azauracil were combined. Treatments were again applied with a hand sprayer until all above-sand tissues were thoroughly wetted and runoff had begun. A randomized block design was used with three replicates for each of the nine treatments.

Both experiments were harvested 6 weeks after treatment. From each replicate, four uniform canes were cut at the sand surface and total fresh weight plus mature stalk weight was recorded immediately. Leaves +1 to +4 and immature storage tissue were quickly frozen in a mixture of Dry Ice and acetone. They were lyophilized, ground to a fine powder with a Wiley mill, and stored at $-20^{\circ} \mathrm{C}$. until needed for enzyme and sugar analysis. Internode lengths were also recorded, as were numerical ratings of visible growth-inhibitor symptoms.

\section{LABORATORY ANALYSBS}

Clarified water extracts of leaf and immature storage tissues were analyzed for total ketose by the resorcinol method of Roe (26), and for sucrose

- Supplied by the Nutritional Biochemicals Corp., Cleveland, 0 .

- Considerable information has been gathered in Puerto Rico concerning GA effects upon growth, enzymology, and sugar production of immature sugarcane. For the present studies GA was used to determine whether 6-azauracil was an effective inhibitor in plants experiencing a powerful growth stimulus. 
by the modification of Cardini et al. (12). Fructose was estimated by subtracting sucrose values from those of total ketose. Mature stalks were ground with a small laboratory mill for Brix and polarization analyses.

Protein was precipitated between 0 and 80-percent saturation with solid ammonium sulfate, as described earlier (1), and employed for enzyme assay without dialysis. The method of Sutherland et al. (28) was used to measure both the water-soluble protein of tissue samples and the protein content of enzyme preparations.

Particular attention was given to certain hydrolytic and oxidative enzymes which have shown correlations with sugar level in cane. Acid phosphatase and ATP-ase was measured by techniques described earlier ( 3 ), as was amylase (5), invertase (4), polyphenol oxidase (7), and peroxidase (6).

TABLE 1-Mean numerical ratings of visible toxicity symptoms for sugarcane treated with 6-azauracil

\begin{tabular}{l|c|c|c|c|c|c|c}
\hline \multirow{2}{*}{$\begin{array}{c}\text { Data } \\
\text { classification }\end{array}$} & \multicolumn{6}{|c}{ Inhibitor concentration (percent solution)- } \\
\cline { 2 - 7 } & 0 & 0.001 & 0.005 & 0.01 & 0.04 & 0.10 & 0.40 \\
\hline Rating' $^{2}$ & 1.0 & 1.3 & 2.3 & 2.7 & 4.7 & 5.7 & 7.0 \\
\hline
\end{tabular}

11 = No symptoms; 7 = severe symptoms. Each figure represents the mean of ratings from three replicates.

2 Recorded 8 days after treatment.

\section{RESULTS AND DISCUSSION}

\section{EXPERIMENT I: INCREASING CONCENTRATION OF 6-AZAURACIL}

\section{Growth responses to 6-azauracil}

Within 72 hours after treatment visible symptoms characteristic of azauracil injury appeared among plants receiving the highest inhibitor level ( 0.40 percent). Symptoms soon intensified so that by 8 days after treatment some evidence of injury was visible among plants given as little as 0.005 percent. Numerical ratings recorded at 8 days are presented in table 1. Severe symptoms included general yellowing of the foliage with localized red to red-brown spots on leaves. Similar spots plus parallel red streaks appeared on sheaths. A solid band of discoloration was often visible at the dewlap. Death of tissues occurred at leaf tips and margins. These symptoms remained generally constant throughout the study and were usually visible on the newly-sprouting tillers.

Newly-formed immature leaves were yellowed and malformed in response to 0.01- and 0.04-percent azauracil, whereas no new tissues emerged at all subsequent to 0.10 - and 0.40 -percent treatments. Plants given 0.10 percent 
of the inhibitor were thoroughly yellowed and stunted at the close of study. All of those receiving 0.40 percent were dead within 15 to 20 days after treatment. Fresh weights recorded at the close of the study indicate that 0.04-percent azauracil was the lowest treatment causing significant growth decline (table 2).

TABLE 2-Mean fresh-weight values for sugarcane treated by foliar application of 6-azauracil1

\begin{tabular}{|c|c|c|c|c|c|c|c|c|}
\hline \multirow{2}{*}{$\begin{array}{l}\text { Grams per } \\
\text { plant for- }\end{array}$} & \multirow{2}{*}{$\underset{0}{\text { Control, }}$} & \multicolumn{6}{|c|}{ Azauracil concentration applied (percent solution)- } & \multirow{2}{*}{$\underset{\text { mean }}{\text { Azauracil }}$} \\
\hline & & 0.001 & 0.005 & 0.01 & 0.04 & 0.10 & 0.40 & \\
\hline Fresh weight & 254 & 249 & 236 & 254 & 180 & 42 & -2 & 192 \\
\hline
\end{tabular}

1 Each figure represents the computed mean of 3 replicates; 4 uniform plants were harvested from each replicate.

2 Plants killed by azauracil treatment.

$\mathrm{T}_{\mathrm{ABL}}$ 3-Leaf sugar content, in milligrams per gram of dry weight, for immature sugarcane treated by foliar application of 6-azauracil 1

\begin{tabular}{l|c|c|c|c|c|c|c|c}
\hline \multirow{2}{*}{ Sugar } & $\begin{array}{c}\text { Control, } \\
0\end{array}$ & \multicolumn{3}{|l|}{ Azauracil concentration supplied (percent solution)- } & \multirow{2}{*}{$\begin{array}{c}\text { Azauracil } \\
\text { mean }\end{array}$} \\
\cline { 2 - 6 } & & 0.001 & 0.005 & 0.01 & 0.04 & 0.10 & 0.40 & \\
\hline Total ketose & 79.6 & 89.3 & 80.3 & 77.4 & 81.2 & 107.9 & -2 & 87.2 \\
Sucrose & 60.4 & 68.4 & 58.5 & 56.9 & 62.3 & 105.8 & -2 & 70.4 \\
Fructose & 19.2 & 20.9 & 21.8 & 20.5 & 18.9 & 2.1 & -2 & 16.8 \\
\hline
\end{tabular}

1 Each figure represents the computed mean of 3 replicates.

2 Plants killed by azauracil treatment.

\section{SUGAR CHANGES IN RESPONSE TO 6-AZAURACIL}

Sugarcane experiencing a severe growth restriction might logically reveal sucrose accumulations. This has been observed when factors such as water (2) or nutrients (8) were of growth-limiting supply, and a similar effect was induced by 6 -azauracil during the present study. Leaf sucrose rose abruptly in response to 0.10-percent azauracil (table 3). Sucrose of immature storage tissue was generally higher in all inhibitor-treated plants (table 4). As little as $\mathbf{0 . 0 1}$ percent of $\mathbf{6 - a z a u r a c i l}$ caused a major sucrose rise, and 0.04 percent yielded close to a fourfold increase over control values. These results support the contention that 6-azauracil can divert sugarcane from a status of sugar utilization to one of sugar storage.

Higher leaf sucrose appeared to be a function both of higher total ketose production and a decline of inversion, the latter being suggested by loss of 
fructose. Total ketose remained constant in immature storage tissue so that suppressed inversion must have accounted for higher sucrose content in that area.

TABLE 4-Sugar content of immature storage tissue from sugarcane treated by foliar application of 6-azauracil1

\begin{tabular}{l|r|r|r|r|r|r|r|r}
\hline \multirow{2}{*}{$\begin{array}{c}\text { Sugar (mg./g. of } \\
\text { dry weight) }\end{array}$} & $\begin{array}{c}\text { Control, } \\
\text { o }\end{array}$ & \multicolumn{3}{|c|}{ Azauracil concentration applicd (percent solution)- } & \multirow{2}{*}{$\begin{array}{c}\text { Azauracil } \\
\text { mean }\end{array}$} \\
\cline { 2 - 8 } & 0.001 & 0.005 & 0.01 & 0.04 & 0.10 & 0.40 & \\
\hline Total ketose & 301 & 339 & 334 & 334 & 334 & -2 & -3 & 335 \\
Sucrose & 34 & 46 & 45 & 99 & 130 & -2 & -3 & 80 \\
Fructose & 267 & 293 & 289 & 235 & 204 & -2 & -3 & 255 \\
\hline
\end{tabular}

1 Each figure represents the computed mean of 3 replicates.

2 Tissue killed by azauracil treatment.

s Plants killed by azauracil treatment.

TABLE 5-Protein content and enzyme specific-activity values of immature storage tissue from sugarcane treated by foliar application of 6-azauracil'

\begin{tabular}{|c|c|c|c|c|c|c|c|c|}
\hline \multirow{2}{*}{$\begin{array}{l}\text { Mean values } \\
\text { for- }\end{array}$} & \multirow{2}{*}{$\underset{0}{\text { Control, }}$} & \multicolumn{6}{|c|}{ Aazuracil concentration applied (percent solution)- } & \multirow{2}{*}{$\begin{array}{c}\text { Azauraci } \\
\text { mean }\end{array}$} \\
\hline & & 0.001 & 0.005 & 0.01 & 0.04 & 0.10 & 0.40 & \\
\hline Protein ${ }^{2}$ & 24.9 & 25.4 & 24.5 & 45.3 & 78.6 & $一^{8}$ & -4 & 43.4 \\
\hline Phosphatase & 17.8 & 16.9 & 17.7 & 10.7 & 5.8 & $-^{8}$ & -4 & 12.8 \\
\hline ATP-ase & 16.8 & 17.0 & 18.3 & 12.1 & 6.9 & -8 & -4 & 13.6 \\
\hline Amylase & 51 & 36 & 54 & 30 & 24 & -8 & -4 & 36 \\
\hline Invertase & 19.9 & 18.3 & 22.1 & 6.5 & 2.9 & -8 & -1 & 12.4 \\
\hline Polyphenol oxidase & 18.1 & 17.6 & 18.9 & 10.8 & 6.2 & - $^{8}$ & -4 & 13.4 \\
\hline
\end{tabular}

1 Each figure represents the computed mean of 3 replicates.

2 Milligrams per gram of dry weight.

3 Tissue killed by azauracil treatment.

- Plants killed by azauracil treatment.

\section{6-azauracil effects upon enzymes}

Although no immature storage tissue remained alive for analysis at the two highest inhibitor levels, very definite trends were obtained for protein and enzymes between the 0.005- and 0.04-percent concentrations (tabie 5). Each of the enzymes assayed declined sharply with increasing inhibitor. At 0.04 percent these tissues appeared to be severely enzyme-deficient. Invertase activity was only about 15 percent of control values. With higher azauracil the tissue may well have died for lack of sufficient catalytic potential to maintain life, especially since this area is normally one of the 
most biochemically active in the entire plant. Inability of the plants to continue growth plus their greatly suppressed enzymology is reflected by a threefold accumulation of water-soluble protein.

Phosphatase, ATP-ase, and amylase from leaves reveal a lesser sensitivity to azauracil than do their counterparts in immature storage tissue (table 6). This helps explain the survival of leaf tissues after the death of the meristem. Nevertheless, severe leaf enzyme suppression was caused by the 0.10 -percent treatment and an upward trend for leaf-protein content was recorded (table 6).

The failure of 6-azauracil to alter leaf catalysts as severely as those of immature storage tissue suggests that the inhibitor was rapidly translocated from the leaves to storage tissue. Possibly it accumulated there. If the chemical joined the normal movement of carbohydrate it should eventually

TABLE 6-Leaf protein content and enzyme specific-activity values for sugarcane treated by foliar application of 6-azauracil 1

\begin{tabular}{|c|c|c|c|c|c|c|c|c|}
\hline \multirow{2}{*}{$\begin{array}{l}\text { Mean values } \\
\text { for- }\end{array}$} & \multirow{2}{*}{$\underset{0}{\text { Control, }}$} & \multicolumn{6}{|c|}{ Azauracil concentration supplied (percent solution)- } & \multirow{2}{*}{$\begin{array}{c}\text { Azauracil } \\
\text { mean }\end{array}$} \\
\hline & & 0.001 & 0.005 & 0.01 & 0.04 & 0.10 & 0.40 & \\
\hline Protein (mg./g.) & 6.4 & 6.6 & 9.3 & 12.6 & 11.9 & 17.5 & -2 & 11.6 \\
\hline Phosphatase & 15.8 & 16.2 & 13.7 & 17.3 & 13.3 & 6.3 & -2 & 13.4 \\
\hline ATP-ase & 17.0 & 19.7 & 19.1 & 26.0 & 18.2 & 7.0 & -2 & 18.0 \\
\hline Amylase & 67 & 67 & 45 & 53 & 44 & 29 & -2 & 48 \\
\hline
\end{tabular}

1 Each figure represents the computed mean of 3 replicates.

2 Plants killed by azauracil treatment.

accumulate in mature stalks. Conversely, the plants may have "mistaken" this compound for free uracil and diverted it to the meristematic area for use in nucleic acid synthesis.

At the moment there is insufficient evidence to propose that growth effects were due entirely to retarded enzyme action. In vitro enzyme studies now in progress should help to clarify this question. However, the observed sucrose accumulation was probably a consequence of the invertase suppression caused by azauracil.

\section{EXPERIMENT II: 6-AZAURACIL $X$ GIBBERELLIC ACID}

\section{Growth responses}

Combinations of GA with 6-azauracil verified growth-inhibitory effects of the latter on sugarcane, and showed that the inhibitor's action is only partly countered by severe growth stimuli. The high azauracil treatment, 0.05 percent, was intended to retard growth while permitting the plants to 
remain alive. This was achieved at all GA levels (table 7). High azauracil did cause death of the meristem tissues at low and medium GA levels, but these tissues remained alive in plants given high GA ( 0.10 percent). The 0.10-percent GA level also tended to counteract the high azauracil suppression of millable stalk weight and internode length (table 7).

A small amount of 6-azauracil, 0.005 percent, increased millable stalk weight, and to a lesser degree increased total fresh weight plus internode length-but only in the presence of high GA (table 7). This is further evidence of an effort by the plant to accept or transform azauracil under conditions of greatly stimulated biochemistry. The plant may have succeeded in converting some of the inhibitor to free uracil. Possibly, the plant reacted to inhibitor traces by increasing nucleic acid synthesis, thereby permitting

TABLE 7-Fresh-weight values and internode lengths of immature sugarcane treated with foliar combinations of gibberellic acid and 6-azauracil', 2

\begin{tabular}{|c|c|c|c|c|c|c|c|c|c|c|c|c|}
\hline \multirow{3}{*}{ GA (percent) } & \multicolumn{12}{|c|}{ Mean values for- } \\
\hline & \multicolumn{4}{|c|}{ Millable stalks (g./stalk) } & \multicolumn{4}{|c|}{ Total fresh weight (g./plant) } & \multicolumn{4}{|c|}{ Internode length (in.) } \\
\hline & uo & u. 005 & 0.03 & Mean & uo & u.cos & u.os & Mean & uo & u. .008 & 0.08 & Mean \\
\hline $\mathbf{0}$ & 121 & 96 & 51 & 89 & 345 & 252 & 121 & 239 & 4.6 & 4.6 & 2.5 & 3.9 \\
\hline .01 & 100 & 109 & 58 & 89 & 250 & 224 & 149 & 208 & 6.0 & 6.3 & 3.7 & 5.3 \\
\hline .10 & 119 & 147 & 79 & 115 & 254 & 268 & 140 & 221 & 7.8 & 8.3 & 4.7 & 6.9 \\
\hline Mean & 113 & 117 & 63 & & 283 & 248 & 137 & & 6.1 & 6.4 & 3.6 & \\
\hline
\end{tabular}

1 Each figure represents the computed mean of 3 replicates. Four uniform plants were harvested from each replicate.

2 The symbol u signifies 6-azauracil.

a slightly greater degree of growth and development. Greater stalk-weight with azauracil also suggests increased physiological maturity, in the presence of high $\mathrm{GA}$, rather than the simple stunting or excessive elongation obtained when the respective chemicals act alone.

\section{$G A \times 6$-azauracil effects on sugar content}

Incomplete data for immature storage tissue show that increasing GA raised the sucrose content (table 8). Similar GA effects have been observed earlier $(20)^{5}$. The 0.005 -percent azauracil treatment appeared to give moderate sucrose increases, and high azauracil combined with high GA yielded the maximum sucrose values for available tissues. Leaf-sugar values reflect the GA and azauracil action to a lesser degree (table 9). High GA combined

$\checkmark$ Data submitted for publication, Proc. Intnl. Soc. Sugar Cane Technol., Taiwan, 1968. 
with high azauracil again gave maximum sucrose values. Leaf fructose content declined sharply in response to both chemicals, suggesting, as in experiment $I$, a suppressed sucrose inversion.

Brix and polarization data for juice of mature stalk tissue generally conform to the sugar changes discussed above. The 0.01-percent level of

TABLE 8-Sugar content of immature storage tissue from sugarcane treated with foliar combinations of gibberellic acid and 6-azauracil ${ }^{1}$

\begin{tabular}{|c|c|c|c|c|c|c|c|c|c|c|c|c|}
\hline \multirow{3}{*}{ GA(percent) } & \multicolumn{12}{|c|}{ Sugar (mg./g. of dry weight)- } \\
\hline & \multicolumn{4}{|c|}{ Total ketose } & \multicolumn{4}{|c|}{ Sucrose } & \multicolumn{4}{|c|}{ Fructose } \\
\hline & u.o & u. .008 & u. 08 & Mean & u.o & u. .003 & 0.05 & Mean & u.o & u. 008 & u.os & Mean \\
\hline $\mathbf{0}$ & 293 & 303 & -2 & $298^{3}$ & 144 & 159 & -2 & $152^{3}$ & 149 & 144 & -2 & $147^{3}$ \\
\hline .01 & 323 & 338 & -2 & $331^{3}$ & 161 & 173 & -2 & $167^{2}$ & 162 & 165 & - & $164^{3}$ \\
\hline .10 & 351 & 387 & 384 & 374 & 181 & 202 & 233 & 205 & 170 & 185 & 151 & 169 \\
\hline Mean & 322 & 343 & $384^{4}$ & & 162 & 178 & $233^{4}$ & & 160 & 165 & $151^{4}$ & \\
\hline
\end{tabular}

1 Each figure represents the computed mean of 3 replicates.

2 Tissues killed by azauracil treatment.

- Mean of low and medium azauracil treatments only.

4 Azauracil mean available only from the high GA treatment.

TABLE 9-Mean values for leaf-sugar content of immature sugarcane treated with foliar combinations of gibberellic acid and 6-azauracil1,2

\begin{tabular}{|c|c|c|c|c|c|c|c|c|c|c|c|c|}
\hline \multirow{3}{*}{ GA(percent) } & \multicolumn{12}{|c|}{ Sugar (mg./g. of dry weight)- } \\
\hline & \multicolumn{4}{|c|}{ Total ketose } & \multicolumn{4}{|c|}{ Sucrose } & \multicolumn{4}{|c|}{ Fructose } \\
\hline & u. & u. .008 & u. .05 & Mean & u.o & u. .008 & u.os & Mean & u.o & u. $00 \mathrm{~s}$ & u. .08 & Mean \\
\hline 0 & 176 & 167 & 149 & 164 & 139 & 133 & 136 & 136 & 37 & 34 & 13 & 28 \\
\hline 0.10 & 175 & 172 & 147 & 165 & 155 & 154 & 146 & 152 & 20 & 18 & 2 & 13 \\
\hline .10 & 174 & 182 & 183 & 179 & 154 & 165 & 179 & 166 & 21 & 18 & 5 & 15 \\
\hline Mean & 175 & 174 & 159 & & 149 & 151 & 154 & & 26 & 23 & 7 & \\
\hline
\end{tabular}

1 Each figure represents the computed mean of 3 replicates.

2 The symbol $\mu$ signifies 6-azauracil.

GA consistently increased both polarization and Brix values (table 10). The combination of medium GA and high azauracil, which killed meristematic tissues, gave the most extensive Brix and polarization increases.

Enzyme responses to $G A$ and 6-azauracil

The azauracil suppression of enzymes in experiment I was again observed in experiment II. Invertase and polyphenol oxidase of immature storage 
tissue was the most severely affected (table 11), and for each catalyst measured the azauracil suppression was intensified by increasing GA. The high inhibitor concentration again increased protein content at the high GA level, the latter being the only high-azauracil treatment with tissues availa-

TABLE 10-Polarization and Brix values for millable stalks of immature sugarcane treated with foliar combinations of gibberellic acid and 6-azauracil1, 2

\begin{tabular}{|c|c|c|c|c|c|c|c|c|}
\hline \multirow{3}{*}{ GA(percent) } & \multicolumn{8}{|c|}{ Mean values for- } \\
\hline & \multicolumn{4}{|c|}{ Polarization } & \multicolumn{4}{|c|}{ Brix } \\
\hline & u. & u. .005 & u.0s & Mean & u. & u. .005 & u.08 & Mean \\
\hline 0 & 17.4 & 19.2 & 30.1 & 22.2 & 10.0 & 10.4 & 11.1 & 10.5 \\
\hline 0.01 & 29.8 & 29.3 & 41.3 & 33.5 & 12.5 & 12.1 & 15.0 & 13.2 \\
\hline .10 & 22.9 & 25.3 & 25.1 & 24.4 & 11.6 & 12.1 & 10.9 & 11.5 \\
\hline Mean & 23.4 & 24.6 & 32.2 & & 11.4 & 11.5 & 12.3 & \\
\hline
\end{tabular}

1 Each figure represents an aliquot sample from 3 combined replicates.

2 The symbol u signifies 6-azauracil.

TABLE 11-Protein content and specific-activity values for enzymes of immature storage tissue from sugarcane treated with foliar combinations of gibberellic acid and 6-azauracil1

\begin{tabular}{|c|c|c|c|c|c|c|c|c|c|c|c|c|}
\hline \multirow{3}{*}{ GA(percent) } & \multicolumn{12}{|c|}{ Mean values for- } \\
\hline & \multicolumn{4}{|c|}{ Protein (mg./g.) } & \multicolumn{4}{|c|}{ Phosphatase } & \multicolumn{4}{|c|}{ ATP-ase } \\
\hline & $\mathbf{u} .0$ & u. .008 & $\mathbf{u}, 08$ & Mean & u.o & u. .005 & u. .08 & Mean & u.o & u. $.00 \mathrm{~s}$ & u. .08 & Mean \\
\hline \begin{tabular}{l}
\multicolumn{1}{l}{$\begin{array}{l}.01 \\
.10\end{array}$} \\
\end{tabular} & $\begin{array}{l}23.9 \\
39.2 \\
42.0\end{array}$ & $\begin{array}{l}30.6 \\
37.5 \\
64.6\end{array}$ & $\begin{array}{c}\text {-2 }^{2} \\
86.2\end{array}$ & $\begin{array}{l}27.2^{3} \\
38.4^{8} \\
64.3\end{array}$ & $\begin{array}{l}17.7 \\
14.3 \\
13.3\end{array}$ & $\begin{array}{r}4.4 \\
13.2 \\
9.0\end{array}$ & $\overline{-2}^{2}$ & $\begin{array}{c}10.9^{3} \\
13.8^{3} \\
8.8\end{array}$ & $\begin{array}{l}21.1 \\
15.2 \\
14.4\end{array}$ & $\begin{array}{l}15.1 \\
11.9 \\
10.9\end{array}$ & $\begin{array}{c}-2 \\
6.1\end{array}$ & $\begin{array}{l}18.1^{8} \\
13.6^{8} \\
10.5\end{array}$ \\
\hline \multirow[t]{2}{*}{ Mean } & 35.0 & 44.2 & $86.2^{4}$ & & 15.1 & 8.9 & $4.1^{4}$ & & 16.9 & 12.6 & $6.1^{4}$ & \\
\hline & \multicolumn{4}{|c|}{ Amylase } & \multicolumn{4}{|c|}{ Invertase } & \multicolumn{4}{|c|}{ Polyphenol oxidase } \\
\hline $\begin{array}{l}0 \\
.01 \\
.10\end{array}$ & $\begin{array}{l}176 \\
115 \\
115\end{array}$ & $\begin{array}{r}131 \\
89 \\
87\end{array}$ & $\frac{-2}{65}$ & $\begin{array}{c}154^{3} \\
102^{3} \\
89\end{array}$ & $\begin{array}{r}10.8 \\
6.9 \\
5.8\end{array}$ & $\begin{array}{l}7.7 \\
5.9 \\
4.3\end{array}$ & $\underset{2.1}{\longrightarrow}$ & $\begin{array}{l}9.3^{3} \\
6.4^{3} \\
4.1\end{array}$ & $\begin{array}{r}11.2 \\
7.4 \\
7.4\end{array}$ & $\begin{array}{l}8.5 \\
7.5 \\
4.4\end{array}$ & $\frac{-2}{3.6}$ & $\begin{array}{l}9.9^{3} \\
7.5^{8} \\
5.1\end{array}$ \\
\hline Mean & 135 & 102 & $65^{4}$ & & 7.8 & 5.9 & 2.14 & & 8.7 & 6.8 & $3.6^{4}$ & 5.1 \\
\hline
\end{tabular}

1 Each figure represents the computed mean of 3 replicates. The symbol u signifies 6-azauracil.

2 Tissues killed by azauracil treatment.

Mean of low and medium azauracil treatments only.

4 Azauracil mean available only from the high GA treatment. 
ble for protein analysis. Leaf enzyme values were decreased to a lesser extent than those of immature storage tissue (table 12). This again suggests a translocation of azauracil from leaf to meristematic areas. Peroxidase declined only at the 0.005-percent level of azauracil, and not at all in the presence of high GA. Leaf protein content was moderately increased by 6 -azauracil.

TABLE 12-Protein content and specific-activity values for leaf enzymes of sugarcane treated with foliar combinations of gibberellic acid and 6-azauracil 1,2

\begin{tabular}{|c|c|c|c|c|c|c|c|c|c|c|c|c|}
\hline \multirow{3}{*}{ GA (percent) } & \multicolumn{12}{|c|}{ Mean values for- } \\
\hline & \multicolumn{4}{|c|}{ Protein (mg./g. of dry wt.) } & \multicolumn{4}{|c|}{ Phosphatase } & \multicolumn{4}{|c|}{ Mean ATP-ase } \\
\hline & u. .0 & $\mathrm{u} .005$ & u. 05 & Mean & u.o & u. 005 & u. .05 & Mean & u.o & u. .005 & u. .05 & Mean \\
\hline 0 & 7.0 & 10.3 & 12.5 & 9.9 & 6.5 & 5.4 & 4.7 & 5.5 & 9.6 & 8.2 & 7.1 & 8.3 \\
\hline .01 & 9.3 & 10.8 & 11.9 & 10.7 & 4.9 & 4.5 & 3.8 & 4.4 & 7.2 & 6.6 & 6.0 & 6.6 \\
\hline .10 & 9.9 & 11.1 & 12.8 & 11.3 & 5.3 & 4.3 & 4.2 & 4.6 & 7.8 & 6.0 & 6.5 & 6.8 \\
\hline \multirow[t]{2}{*}{ Mean } & 8.7 & 10.7 & 12.4 & & 5.6 & 4.7 & 4.2 & & 8.2 & 6.9 & 6.5 & \\
\hline & \multicolumn{4}{|c|}{ Amylase } & \multicolumn{4}{|c|}{ Peroxidase } & \multicolumn{4}{|c|}{ Polyphenol oxidase } \\
\hline 0 & 47 & 32 & 25 & 35 & 45 & 24 & 36 & 35 & 12.4 & 9.3 & 8.0 & 9.9 \\
\hline .01 & 35 & 29 & 21 & 28 & 31 & 25 & 42 & 33 & 10.8 & \begin{tabular}{|l|}
9.2 \\
\end{tabular} & 9.2 & 9.7 \\
\hline .10 & 27 & 23 & 19 & 23 & 25 & 26 & 31 & 27 & 10.2 & 9.5 & 9.2 & 9.6 \\
\hline Mean & 36 & 28 & 22 & & 34 & 25 & 36 & & 11.1 & \begin{tabular}{|l|}
9.4 \\
\end{tabular} & 8.8 & \\
\hline
\end{tabular}

${ }^{1}$ Each figure represents the computed mean of 3 replicates.

2 The symbol u signifies 6-azauracil.

\section{Possible mode of action for 6-azauracil in cane}

At the moment one can only speculate as to the mode of action for 6azauracil growth effects in sugarcane. However, research has progressed along several lines concerning purine and pyrimidine analog activity in plant and animal tissues. These areas include RNA synthesis and enzyme alteration.

By 1953 it was known that the purine derivatives 6-mercaptopurine and 8-azaguanine interfered with synthesis of nucleic acids, but their mode of action was not clear $(14,13)$. 8-azaguanine was found to be incorporated into the RNA of certain micro-organisms, a step involving partial replacement of guanine $(27,19)$. Possibly the first structural analog of pyrimidines known to inhibit RNA synthesis was 5-bromouracil. Its mode of action, in Escherichia coli, was partial replacement of thymine in DNA. A series of 
antimetabolic, 5-substituted uracil analogs are now known to incorporate into DNA in place of thymine, including those bearing a 5-constituent $\mathrm{Cl}$, $\mathrm{Br}, \mathrm{I}, \mathrm{CF}_{3}$, and $\mathrm{NH}_{2}$. These significantly modify both the electronic and $\mathrm{H}$-bonding properties of the pyrimidine ring. However, as early as 1954 Zamenhof and Griboff (29) observed that 5-ethyluracil could not replace thymine as a growth factor for $E$. coli, although it suppressed growth in the presence of thymine. Piechowska and Shugar (23) studied 5-ethyluracil as a thymine analog containing a higher alkyl group which leaves the pyrimidine ring fundamentally unaltered.

Specificity of interactions between pyrimidine and purine constituents of nucleic acids is absolutely essential for stable transmission and expression of genetic information. Analogs which preclude normal nucleic acid structure might thereby disrupt normal tissue growth. This concept is probably as valid for sugarcane as it is for any plant or animal species.

Enzyme studies with compounds related to uracil have not given conclusive evidence for specific mode of action. Baker and Chheda (11) failed to inhibit thymidine synthetase with derivatives of uracil-1-alkanoic acids. Pershin and Fadeeva (22) reported that derivatives of uracil and of barbituric acid were but feeble inhibitors of catalase in vitro. Injection of rats with methylthiouracil, alone or combined with $\mathrm{CCl}_{4}$, was found to increase liver glycogen content and glucose-1-phosphatase activity (21).

With regard to sugarcane, the accumulation of tissue protein is a major clue to azauracil mode of action-assuming for the moment that severe enzyme suppression was not a direct cause of growth decline. It is possible that formation of inert protein increased simultaneously with a decline in the plants' capacity to lay down sufficient catalytic protein. The simplest way to visualize this is by a 6 -azauracil-induced uncoding of nucleic acids carrying the information needed for enzyme synthesis. Alteration of their structure or base sequence is highly probable. A polypeptide chain then formed would not contain the correct amino acid sequence for an active enzyme, nor would it retain the correct intermolecular forces needed for its folding into the precise and characteristic configuration of a discrete enzyme.

Direct action or not, the consecuences of 6 -azauracil action against cane enzymes must include the following: 1, Phosphatase decline accompanied by abnormal organic $P$ to inorganic $P$ ratios. This should also include a lessened hydrolysis of IDPG and G-1-P reserves needed for sugar and starch synthesis; 2 , amylase decline with a loss of polysaccharide-hydrolyzing capacity; 3 , severe invertase suppression with concurrent accumulation of sucrose and nonavailability of stored hexose for metabolic needs; and 4, severe polyphenol oxidase suppression with possible disruption of normal terminal oxidation ( 7$)$. 


\section{Potential value of 6-azauracil to the sugar industry}

Preliminary work has shown definite promise for 6-azauracil as a useful growth inhibitor for sugarcane. There is a definite affinity of the chemical for the active meristematic areas. Its general suppression of enzymes leads us to suspect that reactions critical for growth can be blocked in many biochemical areas. Although but one variety was tested in Puerto Rico, the inhibitor's action is so fundamental to growth that it might readily transcend intervarietal capacity to resist. Perhaps still more important is its effectiveness on chemically stimulated material, youmg plants whose normal rapid growth is compounded with GA. It appears likely that practices leading to maximum tonnage could proceed with the certainty that growth can be stopped in a matter of a few days, and that sugar accumulation will quickly predominate over utilization.

\section{SUMMARY}

Immature sugarcane grown by sand culture was treated with foliar sprays of 6-azauracil, and 6-azauracil combined with gibberellic acid (GA). There were four objectives: 1 , To verify growth-inhibitory effects of azauracil and to define the lowest effective concentration; 2 , to determine whether growth inhibition can be maintained in the presence of a powerful growth stimulus; 3 , to determine the influence of azauracil on protein and sugar constituents of treated plants; and 4, to determine whether inhibitor action can be correlated with activity of essential hydrolytic and oxidative enzymes. One experiment was conducted with seven concentrations of foliar azauracil. A second experiment combined three inhibitor concentrations with three levels of GA. All plants were treated once at 14 weeks of age and a single harvest was made 6 weeks later.

Results are summarized as follows:

1. Azauracil injury symptoms appeared within 72 hours among plants given the highest inhibitor level ( 0.40 percent), and within $S$ days for plants receiving as little as 0.005 percent. Severe symptoms included general yellowing of the foliage with localized red to red-brown spots on leaves. Similar spots plus parallel red streaks appeared on sheaths. $A$ solid band of darkened tissue was often visible immediately below the dewlap. Death of tissues occurred at leaf tips and margins. Newly emerging leaves were yellowed, malformed, and apparently nonfunctional. Tillers were also malformed. Symptoms remained throughout the study.

2. Plants treated with 0.40 -percent azauracil were dead within 15 to 20 days. Meristematic tissues died in those given 0.10 percent, but otherwise the plants survived in a stunted condition. The lowest inhibitor level causing significant growth decline was 0.04 percent.

3. Sucrose accumulated in immature storage tissue in response to increas- 
ing azauracil. As little as 0.01 percent caused a major sucrose rise, and 0.04 percent yielded about fourfold increases. Azauracil caused a general loss of fructose, suggesting a suppression of invertase.

4. Each of the enzymes assayed declined sharply with increasing inhibitor concentration. These included acid phosphatase, ATP-ase, amylase, invertase, polyphenol oxidase, and peroxidase. Based on activity trends from plants surviving the inhibitor treatment, the tissues are believed to have been almost totally deficient of enzyme activity at the time of death. The inhibitor effect was far more pronounced in immature storage tissues than in leaves. This suggests a rapid translocation from leaves to storage areas and possible accumulation in tissue having intense biochemical activity.

5. Water-soluble protein was increased up to threefold by 6 -azauracil in immature storage tissue. A similar but less pronounced effect was found in leaves.

6. Combination of 6-azauracil with GA generally verified growth, sugar, enzyme, and protein effects observed earlier. Growth inhibition was retained at all GA levels. High GA, equivalent to 0.10 percent of the pure acid, partially countered an azauracil suppression of fresh weight, millable stalk weight and internode length. Meristematic tissues were killed by high azauracil, 0.05 percent, but remained alive when high GA was combined with the inhibitor.

7. Evidence suggests that combined azauracil and GA promoted physiological maturity more effectively than either agent acting alone.

S. Gibberellic acid generally incrensed sugar content and retarded enzyme action as a main effect.

9. Brix and polarization values were raised both by GA and 6-azauracil as main effects. Combination of 0.01 -percent $\mathrm{GA}$ with 0.05 -percent azauracil gave the maximum brix and polarization values recorded.

10. Possible mode of action of 6-azauracil in cane is discussed from the standpoint of disrupted nucleic acid synthesis. It is suggested that the precise information needed for synthesis of discrete enzymes is uncoded from nucleic acid carriers, with subsequent deficiency of catalytic potential following in proportion to inhibitor level. Biochemical consequences of hydrolytic and oxidative enzyme deficiency in cane are pointed out.

\section{RESUMEN}

A plantas inmaduras de caña de azúcar cultivadas en arena, se les aplicaron aspersiones foliares de 6-azauracilo y combinaciones de 6 -azauracilo y ácido giberélico (AG). Eran cuatro los objetivos: 1, Verificar los efectos inhibitorios del 6-azauracilo sobre el crecimiento y establecer la más baja concentración efectiva; 2 , determinar si la inhibición del crecimiento se puede mantener en presencia de un vigoroso estímulo al crecimiento; 3, 
determinar la influencia del azauracilo en la proteína y en los azúcares en las plantas tratadas; y 4, determinar si la acción inhibidora puede ser correlacionada con la actividad de las enzimas hidroliticas y oxidantes esenciales. En un experimento se aplicaron siete concentraciones de azauracilo foliar, $y$ en otro se combinaron tres concentraciones de inhibidores con tres niveles de AG. Todas las plantas se trataron una vez a las 14 semanas de edad $y$ se cosecharon de una sola vez 6 semanas más tarde. Los resultados fueron los siguientes:

1. Los efectos nocivos del azauracilo se manifestaron dentro de 72 horas en las plantas sometidas a las más altas concentraciones ( 0.40 por ciento), y dentro de $S$ días en las que recibieron cantidades tan mínimas como 0.005 por ciento. Severos síntomas se manifestaron en el follaje amarillento $y$ manchas de rojizas a pardorojizas. En las vainas aparecieron manchas similares y rayas paralelas de color rojizo. A menudo se veía una banda sólida de tejido oscuro inmediatamente debajo de la solapa. Tuvo lugar una necrosis de los tejidos en las puntas y márgenes de las hojas. Las hojas nuevas se tornaron amarillentas, deformes y aparentemente sin capacidad funcional. Los renuevos también eran deformes. Los síntomas persistieron durante el curso del estudio.

2. Las plantas tratadas con un 0.40 por ciento de 6 -azauracilo murieron entre los 15 y los 20 días. El tejido meristemático murió en las que se trataron con un 0.10 por ciento, pero las demás sobrevivieron aunque sin desarrollarse. El 0.04 por ciento fue el nivel más bajo del inhibidor que afectó significativamente el crecimiento.

3. La sacarosa se acumuló en el tejido reservante tierno al aumentarse el azauracilo. Cantidades tan pequeñas como un 0.01 por ciento produjeron un aumento considerable en los niveles de sacarosa y el 0.04 por ciento aumentó el rendimiento cuatro veces más. El azauracilo causó una pérdida general de la fructosa, lo cual sugiere una supresión de la invertasa.

4. Cada una de las enzimas analizadas disminuyó decididamente con el aumento en la concentración del inhibidor, incluyendo la fosfatasa ácida, la ATP-asa, la amilasa, la invertasa, la oxidasa de polifenol y la peroxidasa. Basándose en la tendencia de las plantas que sobrevivieron al tratamiento de inhibición, se cree que al morir los tejidos mostraban una deficiencia casi total de actividad enzimática. El efecto inhibidor era mucho más pronunciado en los tejidos reservantes tiernos que en las hojas. Esto sugiere una translocación rápida de las hojas hacia las áreas de reserva y una posible acumulación en los tejidos de intensa actividad bioquímica.

5. La proteína hidrosoluble aumentó hasta tres veces en el tejido reservante tierno por efecto del 6 -azauracilo. Un efecto similar, aunque menos pronunciado, se encontró en las hojas.

6. La combinación del 6-azauracilo con el AG verificó en general los 
mismos efectos en el crecimiento, el azúcar, las enzimas y las proteínas que se observaron anteriormente. La inhibición del crecimiento se manifestó a todos los niveles del $\mathrm{AG}$ que se usaron. Los niveles altos del $\mathrm{AG}$, equivalentes a un 0.10 por ciento del ácido puro, parcialmente contrarrestaron la supresión causada por el azauracilo en el peso verde, el peso de las cañas molturables y la longitud de los entrenudos. El tejido meristemático murió el usarse una concentración alta de azauracilo, tal como un 0.05 por ciento, pero sobrevivió al combinarse el inhibidor con una concentración alta de ácido giberélico.

7. La evidencia sugiere que la combinación de azauracilo con el AG estimula el envejecimiento fisiológico con más efectividad que cualquiera de ellos por sí solo.

S. En general, el efecto principal del ácido giberélico fue aumentar el contenido de azúcar y retardar la acción enzimática.

9. El efecto principal del AG y del 6-azauracilo fue aumentar la polarización y el brix. Al combinarse 0.01 por ciento de $A G$ y 0.05 por ciento de azauracilo se obtuvieron los valores máximos del brix y de polarización.

10. Se discute el posible modo en que se ejerce la acción del 6-azauracilo, como una interrupción en la síntesis de los á cidos nucleicos. Se sugiere que la clave de la información necesaria para la síntesis de la enzimas se encuentra en los portadores de ácidos nucleicos, con una subsiguiente deficiencia en el potencial catalítico en proporción al nivel inhibidor. Se señalan las consecuencias bioquímicas de la deficiencia hidrolítica y oxidante de las enzimas en la caña de azúcar.

\section{LITERATURE CITED}

1. Alexander, A. G., Sucrose-enzyme relationships in immature sugarcane as affected by varying levels of nitrate and potassium supplied in sand culture, $J$. Agr. Univ. P.R. $48(3): 165-231,1964$.

2. - Physiological studies of enzymes catalyzing the synthesis and hydrolysis of sucrose, starch, and phosphorylated hexose in sugarcane, J. Agr. Univ. P.R. 49(1): 60-75, 1965 .

3. - - Hydrolytic proteins of sugarcane: The acid phosphatases, J. Agr. Univ. P.R. 49(2): 204-28, 1965.

4. - Hydrolytic proteins of sugarcane: The acid invertases, J. Agr. L'niv. P.R. 49(3): 287-307, 1965.

5. - Hydrolytic proteins of sugarcane: Amylase, J. Agr. Cniv. P.R. 49(3): 308-24, 1965.

6. - The oxidizing enzymes of sugarcane: Peroxidase, J. Agr. Lnir. P.R. 50(1): $36-52,1966$.

7. - The oxidizing enzymes of sugarcane: Tyrosinase (polyphenol oxidase), $J$. Agr. Univ. P.R. 50(2): 113-30, 1966.

8. - Abnormal enzyme activity as an early indicator of nut rient deficiency in plants, Proc. Intnl. Colloquium on Plant Analysis and Fertilizer Problems, College Park, Md., 1966. 
9. - Interrelationships of gibberellic acid and nitrate in sugar production and enzyme activity of sugarcane, $J$. Agr. Univ. P.R., 52(1): 19-29.

10. Annual Rept. Exp. Sta. Haw. Sugar Planters Assn., 1966, p. 2. 1965, p. 1.

11. Baker, B. R., and Chheda, G. B., Nonclassical antimetabolites. XVIII. Simulation of 5-phosphoribosyl binding. 2 uracilalkanoic acids related to 2-deoxyuridylate, J. Pharm. Sci. 54(1): 25-30, 1965.

12. Cardini, C. E., Leloir, L. F., and Chiriboga, J., The biosynthesis of sucrose, J. Biol. Chem. 214: 149-55, 1955.

13. Conference on 6-mercaptopurine, biology section of the New York Academy of Sciences. Co-chairmen: Hitchings, G. H., and Rhoads, C. P., Ann. New York Acad. Sci. 60: 183-508, 1954.

14. Elion, G. B., Singer, S., and Hitchings, G. H., The purine metabolism of a 6mercapt opurine-resistant Laclobacillus casei, J. Biol. Chem. 204: 35-41, 1953.

15. Klimek, M., Thymidine incorporation into mammalian strain L cells after the action of 5-fluorodeoxyuridine and the effect of uracil, Neoplasma 12(5): 465-8, 1965.

16. Lasnitski, I., Matthews, R. E. F., and Smith, J. D., Incorporation of 8-azaguanine into nucleic acids, Vature 173: 346-8, 1954.

17. Lindenmayer, A., and Schoen, H. F., Selective effects of purine and pyrimidine analogs and of respiratory inhilbit ors on perit hecial development and branching in Sordaria, Plant Physiol. 42: 1059-70, 1967.

18. Mandel, H. G., Sugarman, G. I., and Apter, R. A., Fractionation studies of Bacillus cereus containing 8-azaguanine. Jour. Biol. Chem. 225: 151-6, 1957.

19. Mandel, H. G., Incorporation of 8-azaguanine and growth inhibition in Bacillus cereus, J. Biol. Chem. 225: 137-50, 1957.

20. Mandel, H. G., Carló, P. E., and Smith, P. K., The incorporation of 8-azaguanine into mucleic acids of tumor-bearing mice, J. Biol. Chem. 206: 181-9, 1954.

21. Milcu, S. M., Biener, J., Costiner, E., and L. Vaisler, Hepatotropic action of methylt hiouracil, Rev. Intern. Hepalol. 14(8): 739-43, 1964.

22. Pershin, G. N., and Fadeeva, N. I., Effects of mercapt oamino compounds and uracil derivatives on catalase activity, Farmakol. $i$ Toksikol. 28(2): 221-3, 1965.

23. Piechowska, M., and Shugar, D., Replacement of 5-methyluracil (thymine) by 5-ethyl uracil in bacterial DNA, Biochem. Biophys. Res. Commun. 20(6): 768-73, 1965.

24. Raghavan, V., Action of purine and pyrimidine analogs on the growth and differentiation of the gametophytes of the fern Asplenium nidus, Amer. J. Bot. $52(9)$ : 900-10, 1965.

25. Rhoads, C. P., Antimetabolites and eancer, American Association for the Advancement of Science, Washingt on, D.C., 1955.

26. Roe. J. R., A colorimetric method for the determination of frutctose in blood and urine, J. Biol. Chem. 107: 15-22, 1934.

27. Smith, J. D., and Mat thews, R. E. F., The metabolism of 8-azapurines, Biochem. J. $66: 323-33,1957$.

28. Sutherland, E. W., Cori, C. F., Iaynes, R., and Olsen, N. S., Purification of the hyperglycemic-glycogenolytic factor from insulin and from gastric mucosa, J. Biol. Chem. 180: 825-33, 1949.

29. Zamenhof, s., and Groboff, G., E. coli cont aining 5-bromouracil in its deoxyribonucleic acid, Nature 174: 306-8, 1954. 